\title{
Benchmarking of a bidimensional flood analysis with a structural measure in the catchment Rosarito Huahuatay Baja California Sur, Mexico
}

\author{
C. Faustino De Luna ${ }^{1 a}$, M. Oscar A. Fuentes ${ }^{1}$, G. Horacio Rubio ${ }^{2}$ and M. Laura Vélez ${ }^{1}$ \\ 1 Instituto de Ingeniería UNAM - Universidad Nacional Autónoma de México, Av. Universidad No.3000 Coyoacán, México D.F. \\ ${ }^{2}$ Comisión Nacional del Agua, Coyoacán México D.F.
}

\begin{abstract}
The main objective of the research reflects the great need to generate hazard maps and calculate risk in the basin Huahuatay Rosarito in Baja California Sur, Mexico.

For the topography in the study area, it is associated with a basin with fast response to rainfall - runoff relationship, because of that is considered necessary to establish the cell size of $50 \mathrm{~m}$ side and a time increment of 0.65 seconds.

The estimate of the flow of water on the surface from the rain was based on the characterization of soils and vegetation cover, through the called number of the runoff curve proposed by the Soil Conservation Service.

Flood areas calculated with a mathematical model of two-dimensional hydraulically from rain (FLUBIDI); they are sensitive to the quality of the input data. Thus, a digital terrain model with good resolution is undoubtedly necessary, and it depends on the path of the runoff.

A good estimate of the effective rainfall, in time and space allows for a volume of runoff, flood areas and depths according to the hydraulic conditions of the study area.

The size of the elements of the mesh used in the calculations generally is higher than the resolution of digital terrain models available, so that processing time would be suitable and which are related to cell size. The results successfully represent runoff within the watershed. Appropriate selection of the value of the friction coefficient of the Manning formula influences, largely, in the magnitudes of the velocities and depths of flow.

Maps maximum depths, maximum speed and severity parameter (or multiplication deep drag velocity) for return periods of two, 5, 10, 50 and 100 years for river floods and storm were obtained.

The maximum values that appear in the maps refer to the largest amount came to present at a certain point in each of the cells in the spreadsheet grid. Maps where the expected damage is presented annually were also developed. The damages were estimated at 60,250 homes and be led risk analysis for return periods from 2 to 100 years. Not necessarily, the works are constructed to reduce flood damages. Sometimes the water that temporarily occupied an area of land can be shifted to other areas where it could cause further injury; it is therefore advisable to make comprehensive basin-wide studies to evaluate the goodness of the proposed works, usually with simulation models embracing the basin where the floodplains are located..
\end{abstract}

\section{Objective}

The main objective of the research is due to the great need to generate hazard maps and calculate the risk in the basin Huahuatay Rosarito in Baja California Sur, Mexico.

\section{Introduction}

By topographic features in the study area, it is associated with a basin with quick response to rainfall runoff relationship, which was considered necessary to establish the cell size of $50 \mathrm{~m}$ side and increased time of 0.65 seconds.

The estimate of water flows on the surface from the rain was based on the characterization of soils and vegetation cover, through the called number runoff curve proposed by the Soil Conservation Service.

Flood areas calculated with a mathematical model of the hydraulic type in two dimensions from rain, are sensitive to the quality of the input data. Thus, a digital terrain model with good resolution undoubtedly

\footnotetext{
a FLunaC@iingen.unam.mx
}

necessary, since it depends on the path followed by the runoff.

A good estimate of the effective rainfall both in time and in space allows for a volume of runoff, flood areas and depths according to the hydraulic conditions of the study area.

The size of the elements of the mesh used in the calculations usually is greater than the resolution of digital terrain models available, so that processing times were appropriate and which are related to cell size.

The size of the elements of the mesh used in the calculations, is greater than the usually resolution of digital terrain models available, so That Were Appropriate processing times and which are related to cell size.

The results successfully represent runoff within the watershed. Appropriate selection of the coefficient of friction of the Manning formula, influences largely, in the magnitudes of the velocities and depths of flow. 
Be obtained maps of maximum depths, maximum speed and severity parameter for return periods of 2,5 , 10,50 and 100 years for river floods and storm.

The maximum values shown in the maps refer to the largest amount came to present at some point in each of the cells in the spreadsheet grid. Figures where the expected damage be presented annually were also developed.

Affectations in 60,250 homes were calculated and be generated risk analysis for return periods of 2 to 100 years.

Not necessarily, the works that are constructed reduce flood damages. Sometimes the water that temporarily occupied an area of land can be moved to other regions where it could cause further injury; therefore, it is convenient to carry out comprehensive studies of a whole watershed to evaluate the goodness of the proposed works, usually with simulation models covering the basin where flood areas are located.

\section{Study area}

Region I (Basin Organization of the Baja California Peninsula and part of Sonora, Mexico), is located northwest of the country, has an area of approximately $145.489 \mathrm{~km}^{2}$. This region in turn sub-regions is divided into two: Baja California and Baja California Sur. Surface water for the whole area is scarce due to low rainfall and high temperatures are present. Most are intermittent and torrential runoffs. Figure 1.

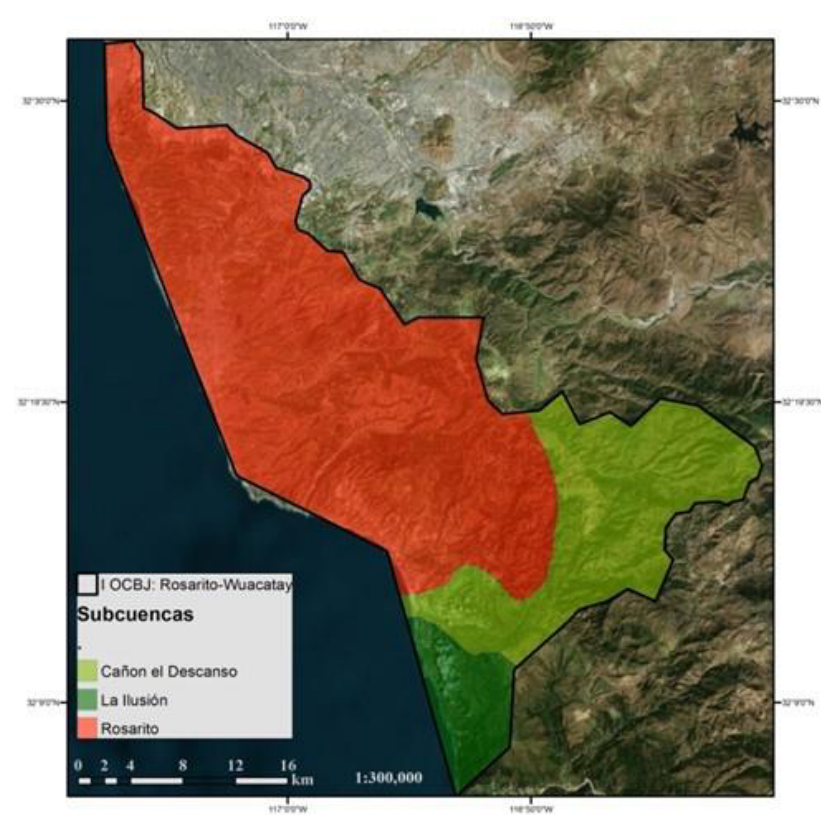

Figure 1. Study area

Based on information from trains rainfall that relate to flooding overflow channels or by the accumulation of rain in the catchment (precipitation of own basin) they were chosen.

The calculation of effective rainfall was performed with the curve number method, proposed by the Soil Conservation Service S.C.S. United States of America in 1964, now National Resources Conservation Service (N.R.C.S.). Figure 2.
With the effective rainfall method or excess rainfall is estimated from the total precipitation and rain discounting sheet it is lost by infiltration, evapotranspiration, interception and surface storage.

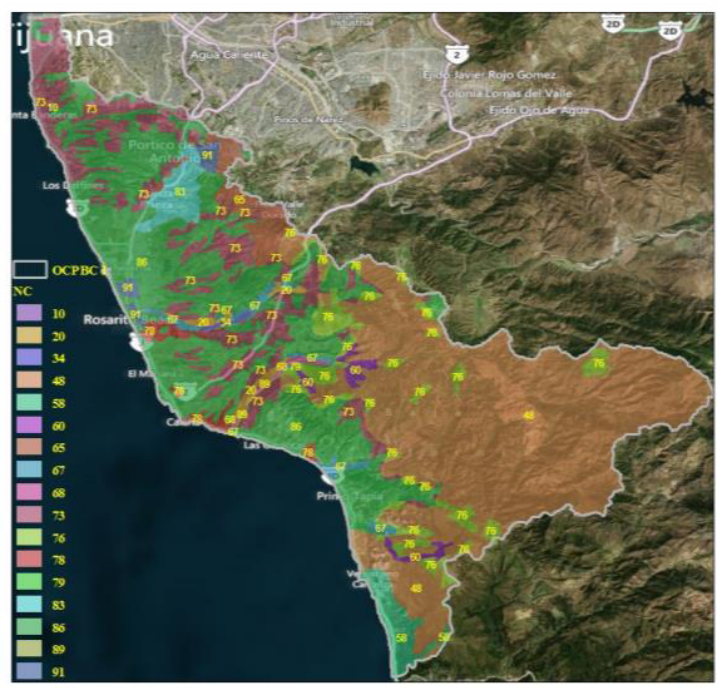

Figure 2. Distribution of runoff curve numbers

For calculations of effective precipitation by thunderstorms or continuous mean value of the number of runoff of the basin, which was estimated at 69.2 units it was considered. The maximum loss sheet $\mathrm{S}$ is equal to $112.6 \mathrm{~mm}$, and the threshold of sheet initial loss is equal to $22.5 \mathrm{~mm}$.

To understand the behaviour of trains storm that frequently occur in the study region, we proceeded to the collection of daily information rainfall recorded at weather stations in the area, using for this purpose the database CLICOM.

The procedure was to identify stations located around the basin area of Rosarito Huahuatay, particularly those whose records are large enough.

In the study area, the length of storm that historically have generated greater accumulation of rain does not exceed three days.

However, a review of the physiographic characteristics of the basin of $658 \mathrm{~km}^{2}$, allowed estimating their concentration time is about three hours. Under these conditions, analysis of surface flows within the basin of interest only made under consideration of the rain temporarily distributed 24 hours a day.

Hyetographs calculation sheets precipitation for less than one day duration curves defined using the intensity duration - return period published by the National Centre for Disaster Prevention (CENAPRED)

Intending to verify the operation of the hydraulic basin, was revised the availability of hydrometric records on the channels that make up the drainage of the basin.

It was noted that the region of interest does not have records of runoff that reveal the variation in spending time on their channels, so the analysis of flows in this area was carried out only with information from rainfall recorded by weather stations available.

According to the physiographic characteristics of the basin of Rosarito, particularly of the magnitude of the 
surface of $658 \mathrm{~km}^{2}$, it is hardly appropriate to apply the concept of simultaneity factor, because during the analysis of precipitation data has been considered that the answer basin can be faster than the duration of rainfall higher historical accumulation registered in the region.

\section{Materials and methods}

Among the materials used for the development of this research was the use of a digital elevation model used for numerical simulation was a combination of information from "United States Elevation Data ( NED ) (10m Resolution) (Use http : // seamless .usgs.gov / ) " LiDAR and INEGI with resolution of $5 \mathrm{~m}$ by $5 \mathrm{~m}$, but that does not cover the entire area under study. Figure 3.

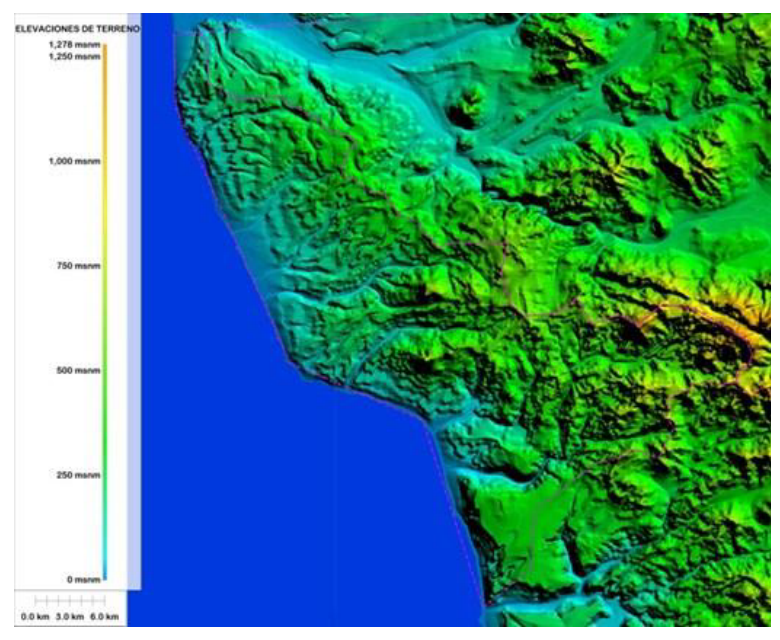

Figure 3 Digital Elevation Model in the study area

To perform mathematical modeling a digital elevation model with a resolution of $50 \mathrm{~m}$ by $50 \mathrm{~m}$ was used as it was considered that the resolution results were obtained with sufficient resolution in a timely and mathematical calculation.

The mesh considered in the mathematical model 881 columns by 1,021 rows corresponding to $685 \mathrm{~km}^{2}$. To achieve numerical stability in mathematical modeling considering the cell size of $50 \mathrm{~m}$ by $50 \mathrm{~m}$ and taking into account that the slope is strong mostly considered the passage of time is 0.6 seconds.

Precipitation. The data considered for mathematical modeling range from $22.7 \mathrm{~mm}$ in 24 hours $(9.3 \mathrm{~mm}$ in one hour) for a return period of 2 years to $83.3 \mathrm{~mm}$ in 24 hours (34.0 $\mathrm{mm}$ in one hour) associated with a return period 100 years. Figure 4

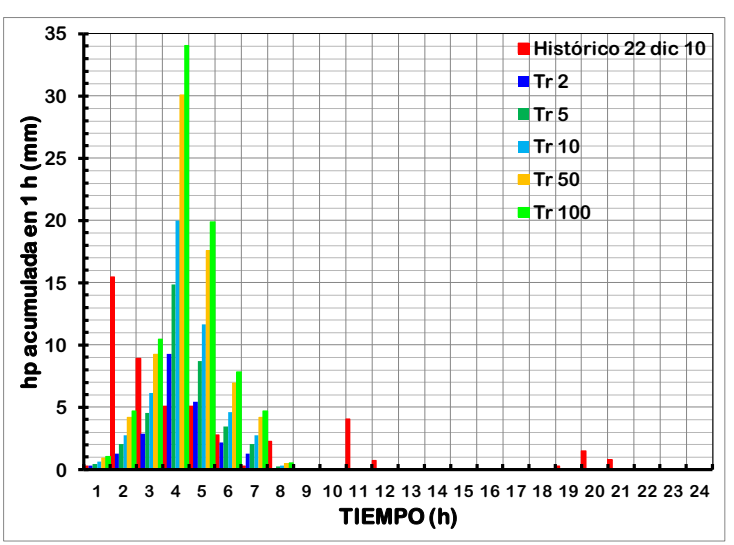

Figure 4. Hyetographs times considered in the study area

In the figure above the histogram of a registered event on 22 December 2010 where the maximum 1-hour accumulated rainfall is $15.5 \mathrm{~mm}$ and 24-hour rainfall recorded corresponds to $47.5 \mathrm{~mm}$ it is included.

\section{Mathematical model}

Phenomena distribution on a spatial continuous medium requires the description with magnitudes evaluated at every moment and in every point in space. Thus in models expressing the rate of change of the descriptive variables are the partial derivatives also take into account the spatial variation.

Kind of partial differential equations are known analytical solutions, but in general, it is necessary to find approximate solutions as much as possible or necessary, to the exact solutions (unknown). To calculate the flow of rain water on the ground are used for the conservation of momentum for a two-dimensional flow (Mahmood and Yevjevitch, 1975)

$$
\begin{aligned}
& \frac{\partial u}{\partial t}+u \frac{\partial u}{\partial x}+v \frac{\partial u}{\partial y}+g \frac{\partial h}{\partial x}=g\left(S_{x}-S_{f x}\right) \\
& \frac{\partial v}{\partial t}+u \frac{\partial v}{\partial x}+v \frac{\partial v}{\partial y}+g \frac{\partial h}{\partial y}=g\left(S_{y}-S_{f y}\right)
\end{aligned}
$$

Because changes in the water velocity on the ground are small, the derivatives of $\mathrm{u}$ and $\mathrm{v}$ with respect to $\mathrm{x}$ and $\mathrm{y}$ are eliminated the above equations, so that, by dividing the acceleration of gravity is

$$
\begin{aligned}
& \frac{1}{g} \frac{\partial u}{\partial t}+\frac{\partial h}{\partial x}=\left(S_{x}-S_{f x}\right) \\
& \frac{1}{g} \frac{\partial v}{\partial t}+\frac{\partial h}{\partial y}=\left(S_{y}-S_{f y}\right)
\end{aligned}
$$

For calculating the slopes of friction, it proposed the use of Manning Strickler formula

$$
S_{f x}=\frac{n^{2}|u| u}{h^{4 / 3}}
$$




$$
S_{f y}=\frac{n^{2}|v| v}{h^{4 / 3}}
$$

If deemed to equations 5 and 6 in equations 3 and 4 we see that

$$
\begin{aligned}
& \frac{1}{g} \frac{\partial u}{\partial t}+\frac{n^{2} \mid u \psi}{h^{4 / 3}}=-\frac{\partial h}{\partial x}-\frac{\partial z}{\partial x} \\
& \frac{1}{g} \frac{\partial v}{\partial t}+\frac{n^{2}|v| v}{h^{4 / 3}}=-\frac{\partial h}{\partial y}-\frac{\partial z}{\partial y}
\end{aligned}
$$

Equations 7 and 8 are equations describing the dynamics of momentum conservation whereas the flow takes place on a plain. The principle of conservation of mass in two dimensions horizontal is

$$
\frac{\partial h}{\partial t}+\frac{\partial}{\partial x} u h+\frac{\partial}{\partial y} v h=q
$$

Where $\mathrm{q}$ is the volume of effective rainfall that enters per unit time and unit area. This expression is also called continuity equation. To calculate the flow of water in a flood plain must solve the system of differential equations formed by the expressions 7,8 and 9 considering certain initial and boundary conditions.

As there is no analytical method for the solution of the equations above, to give an approximate solution of the same, we propose a method of finite differences.

For the application of the mathematical model were written several computer programs in Visual Basic language. The application of computer programs was exhaustive and it was necessary to simulate many possible options to define hydraulic conditions for various probabilities of occurrence overflow flooding rain river basin itself.

\subsection{Mathematical model results}

With the results inundation areas and speed, for various return periods were made the Figures 5, 6, 7, 8, and 9.

A product resulting from the mathematical modeling corresponds to the envelope of depths and maximum speeds. In other words, a map with maximum values, which are not necessarily the same simulation time as the process, the maximum values may occur at different times but the worst value considered, is the maximum.
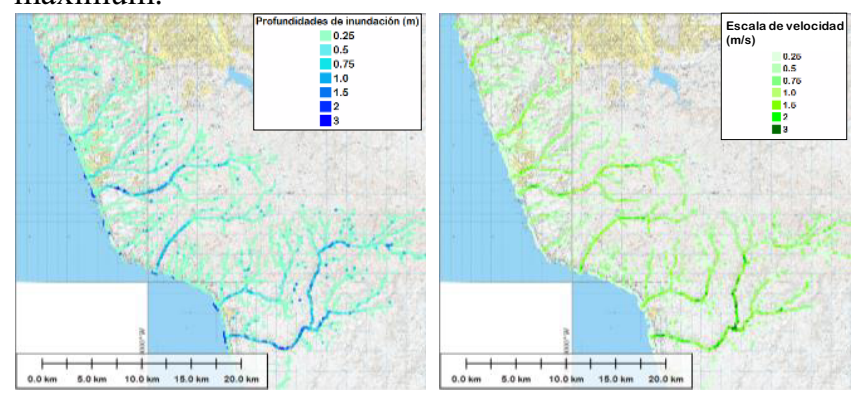

Figure 5. Envelopes maximum values resulting from the mathematical modeling for return periods of 2 years
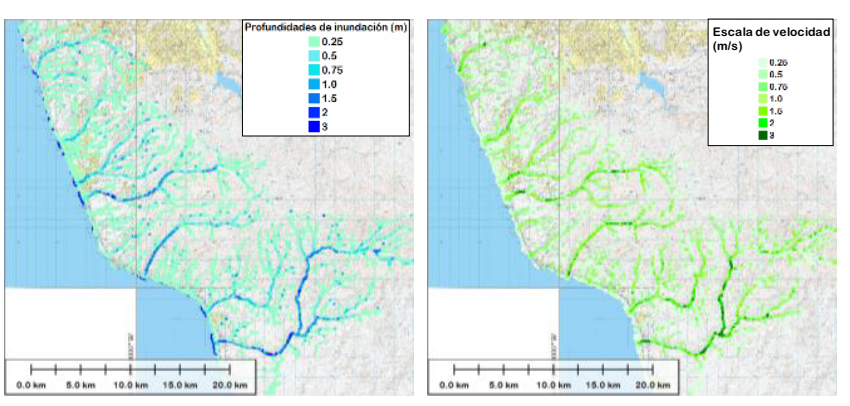

Figure 6. Envelopes maximum values resulting from the mathematical modelling for return periods of 5 years
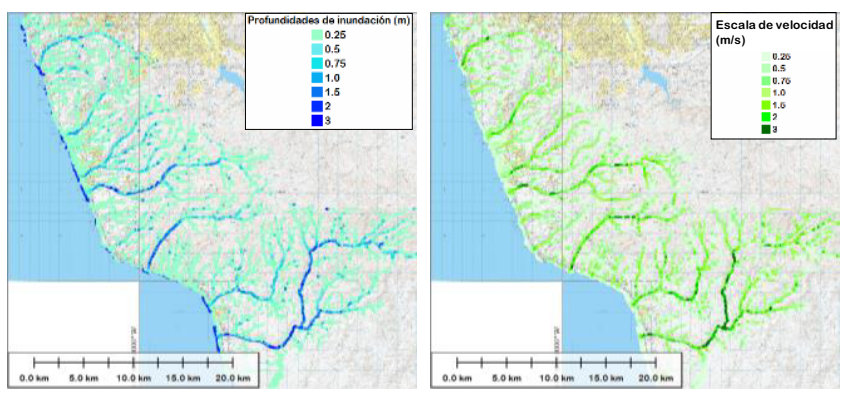

Figure 7. Envelopes maximum values resulting from the mathematical modelling for return periods of 10 years
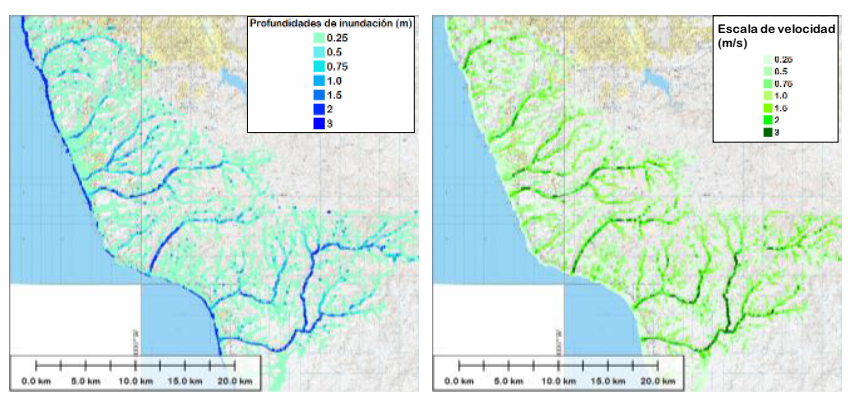

Figure 8. Envelopes maximum values resulting from the mathematical modelling for return periods of 50 years
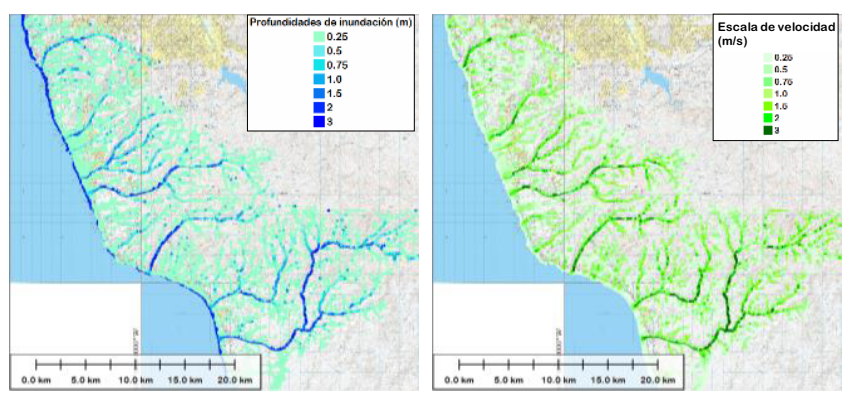

Figure 9. Envelopes maximum values resulting from the mathematical modelling for return periods of 100 years

\section{Vulnerability and Severity}

Below presents the definition of vulnerability and vulnerability index.

Increasing depth and water speed, the damage increase. At higher speeds, the water has greater capacity to transport objects. The damage will be considerable if it erodes the riverbed and will depend on the magnitude of the force of impact. It has called vulnerability to the susceptibility of the houses were damaged when a threat 
of certain intensity occurs. (For the case study, the houses and their contents or furniture).

Vulnerability index is the proportion of the total cost of the damage to houses where some flooding occurs is calculated as follows:

$$
D=I v C
$$

Where:

$$
\begin{aligned}
& \text { C Total cost of damage } \\
& \text { IV Vulnerability index (between } 0 \text { y } 1 \text { ) }
\end{aligned}
$$

Risk: It is up to the expectation or expected value of losses, produced by the occurrence of a phenomenon of natural or anthropogenic origin, a particular physical or social entity set. (10 and 11)

The dictionary of the Royal Spanish Academy, says that risk means, contingency or proximity of damage (12).

$$
R=E(D)=p_{1} D_{1}+p_{2} D_{2}+p_{3} D_{3}+\cdots+p_{n} D_{n}=\Sigma p D
$$

When vulnerability analysis is carried out in a community exposed to flood danger, the best way to reduce vulnerability, identifies the most vulnerable households and consequently take corrective measures.

In the case of civil protection, vulnerability is focused on damage of population and their property. Because of this, to exemplify the vulnerability, just imagine the damage caused to the interior of the housing (household) for the water inlet; and secondly, the damage to the house itself.

Below it is presented in Table 1 severity index by color and in Figures 10 and 11 for the severity return periods of 2 and 100 years.

\begin{tabular}{|c|c|}
\hline Index & Colour \\
\hline Very High & Red \\
\hline High & Orange \\
\hline Middle & Yellow \\
\hline Low & Blue \\
\hline Very low & Green \\
\hline
\end{tabular}

Table 1. Colour Scale considered for the analysis of severity (flood hazard index).

\subsection{Severity maps}

In December 2007, the government of New South Wales (Australia) requested a study Bielsdown River, which passes through a town called Dorrigo in order to determine an appropriate risk management in the floodplain.
This study was conducted to define the levels and velocity of flood, Tool that was decided to use for the present study. Figure 15 shows valuable data regarding flow "velocity/hydraulic flood depth" (resistance to tipping the walls of the houses) .Considering this concept; we have named the product severity as shown.

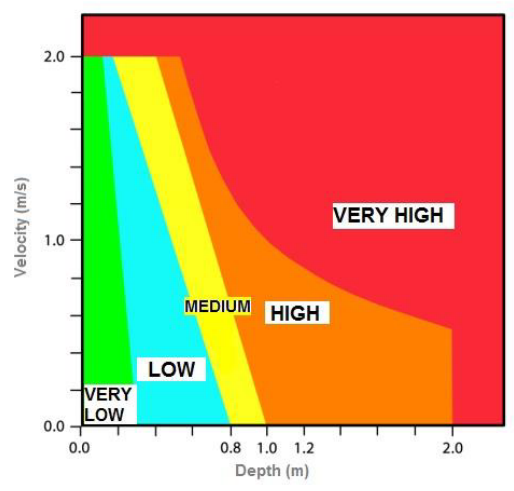

Figure 10 Color scale

Thus, with maximum depths and certain maximum speeds, by considering the graph in Figure 10, it can be obtained maps of severity, where the color scale indicates in red the worst option. Severity maps for each return periods analyzed are presented in the following figure 11 and 12.

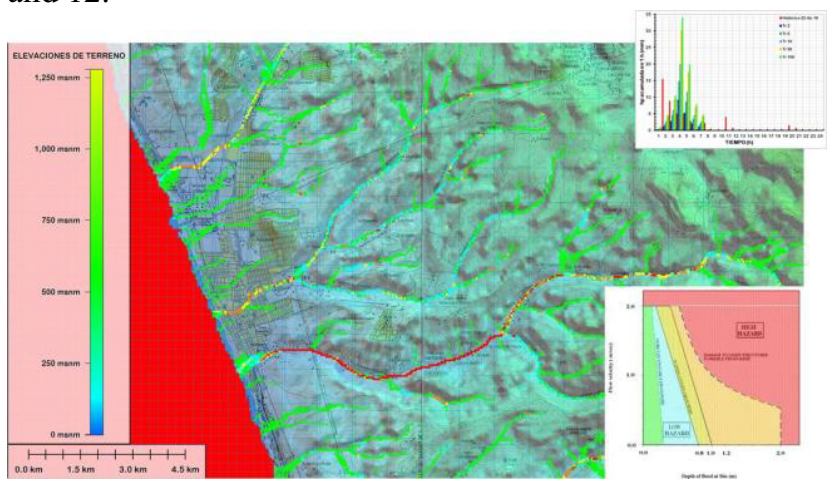

Figure 11. Severity for a return period of 2 years

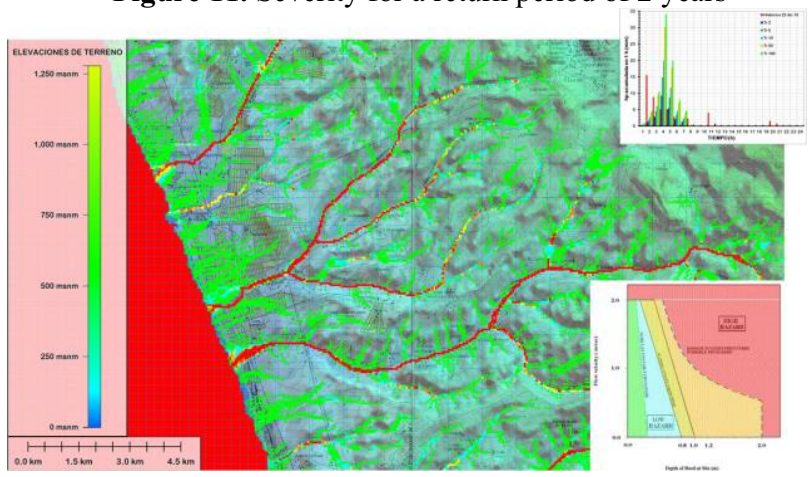

Figure 12 Severity for a return period of 100 years

As a result of mathematical modeling is obtained for each cell analysis of $50 \mathrm{~m}$ x $50 \mathrm{~m}$ side, the value of the severity (flood hazard index) graphically where the energy of the water flow indicated.

Housing risk (expected annual damage), analyzed 6,285 homes that have flooded. Total risk \$ 6'623,377 per year (figure 13 and 14). Table 2. The risk for housing has 
agreed a scale of 6 colors, with intervals from 0 to 58.000 pesos per year.

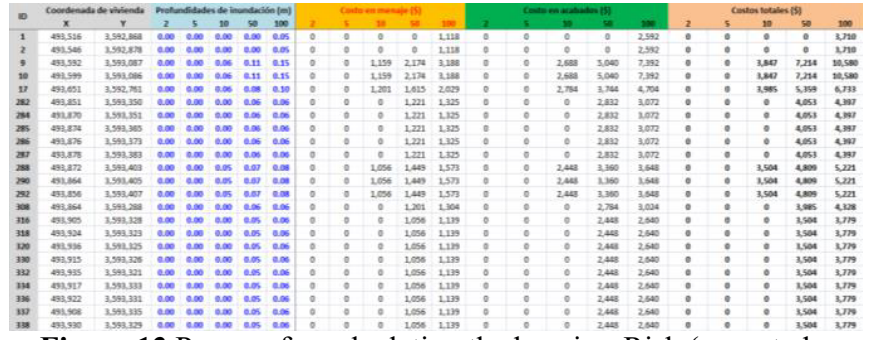

Figure 13 Process for calculating the housing-Risk (expected annual damage)

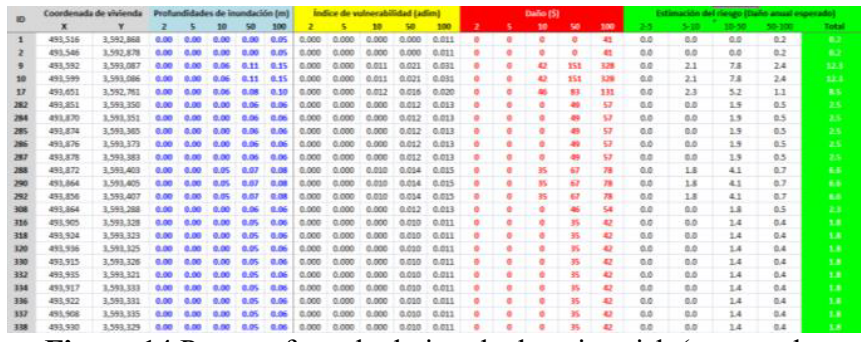

Figure 14 Process for calculating the housing risk (expected annual damage)

Table 2 Summary of risk estimation

\begin{tabular}{|c|c|c|c|c|}
\hline \multicolumn{2}{|c|}{ Risk Range ( \$ / year) } & \% & Housing \\
\hline 0 & To & 600 & 91.7 & 5,763 \\
\hline 600 & To & 6,000 & 5.0 & 314 \\
\hline 6,000 & To & 12,000 & 0.6 & 38 \\
\hline 12,000 & To & 24,000 & 0.7 & 44 \\
\hline 24,000 & To & 36,000 & 1.3 & 82 \\
\hline 36,000 & To & 58,000 & 0.7 & 44 \\
\hline
\end{tabular}

Figure 15 shows the results of the risk estimate (expected annual damage) is presented graphically

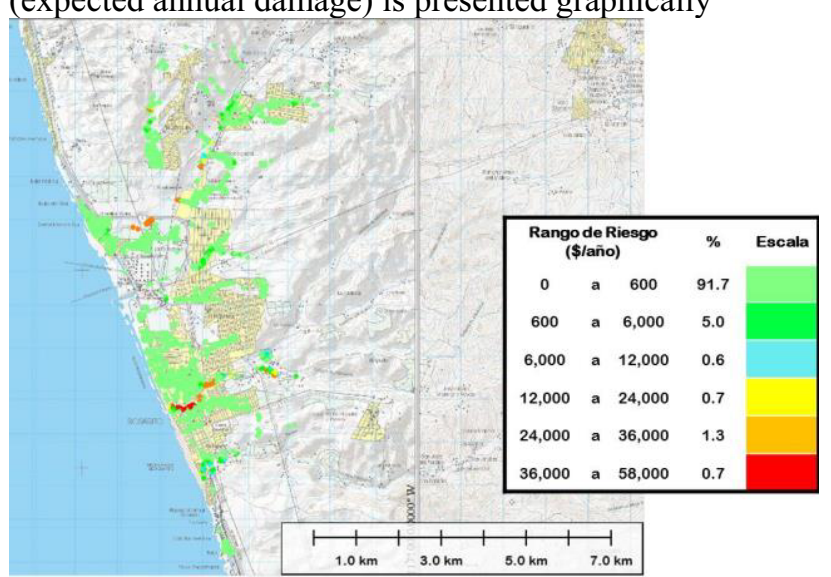

Figure 15 Estimated flood risk in housing

\subsection{Hydraulic evaluation of a structural measure}

Risk management promotes identifying threats, assessing and minimizing risk, using appropriate policies and practices.

Management of flood risks also covers the work to reduce hazards through measures such as land use and spatial planning that take into account the danger of floods, the systems of early warning, evacuation plans , preparing aid disaster and protection of elements located in flood-prone areas and, as a last resort, insurance and other risk-sharing mechanisms.

In the case of Rosarito Huahuatay, it is proposed as a structural measure placing levees or dams, with the aim of reducing flood areas and thus bring down the risk. Figure 16 and 17.

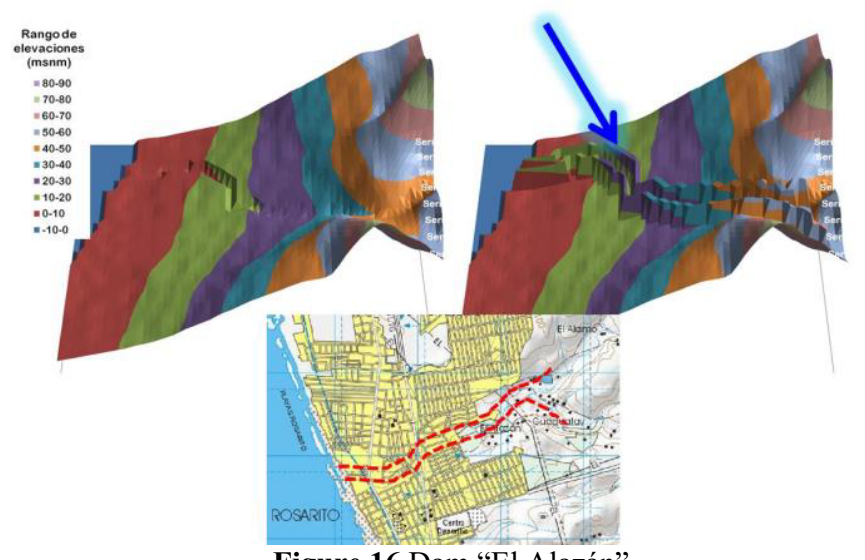

Figure 16 Dam "El Alazán".

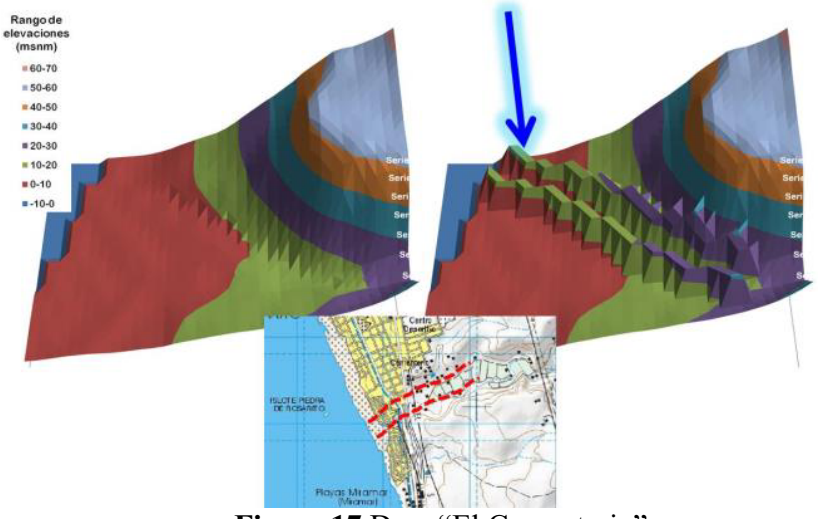

Figure 17 Dam "El Cementerio".

According to Figure 18, shows that current conditions stain flooding in urban areas is higher than for the conditions levees. also shown in Figure 19 the severity for the two conditions

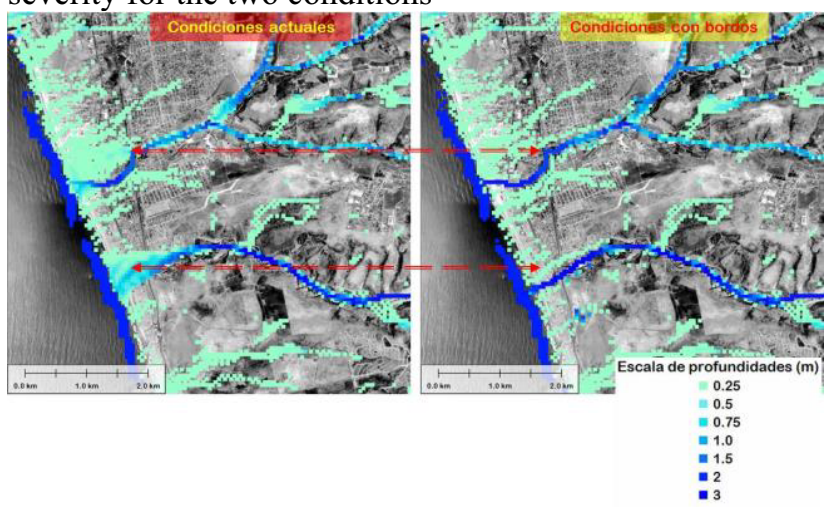

Figure 18 Comparison of initial conditions and dams 


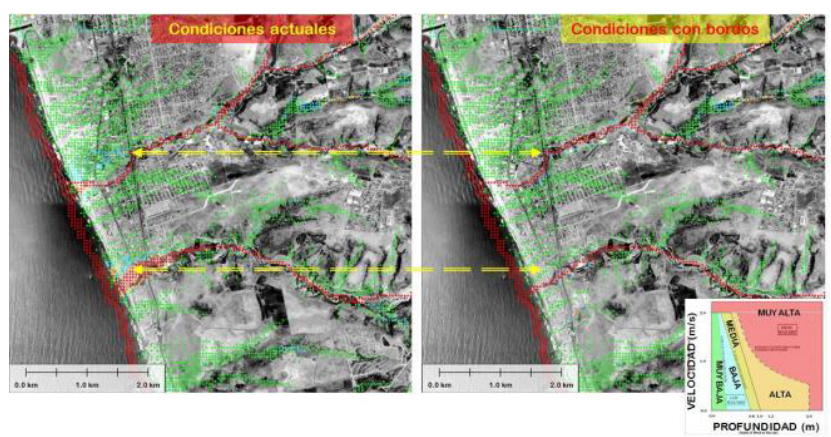

Figure 19 Comparison of severity

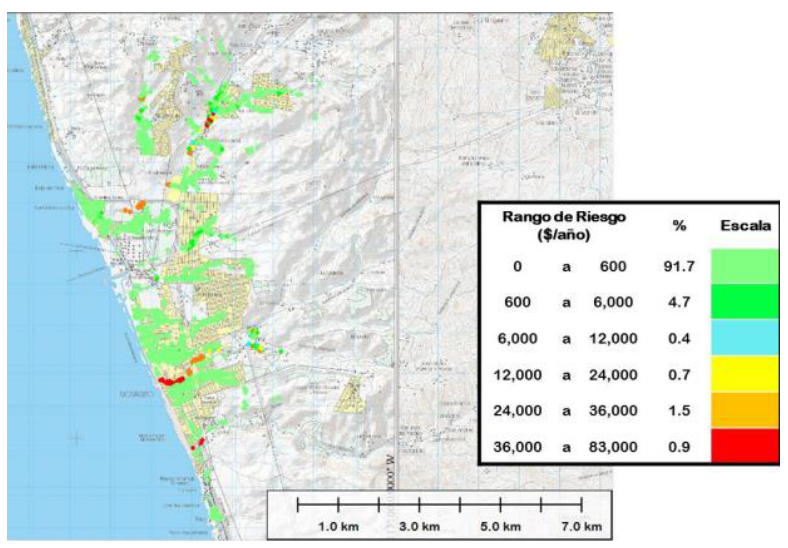

Figure 20 Flood risk estimation in housing with dams

From the previous estimate shown in Figures 20 and 21 , for initial conditions the risk is $\$ 6^{\prime} 623,377$ per year and for conditions with dams is $\$ 77^{\prime} 804,933$, the result is that the risk does not abate, conversely increases.

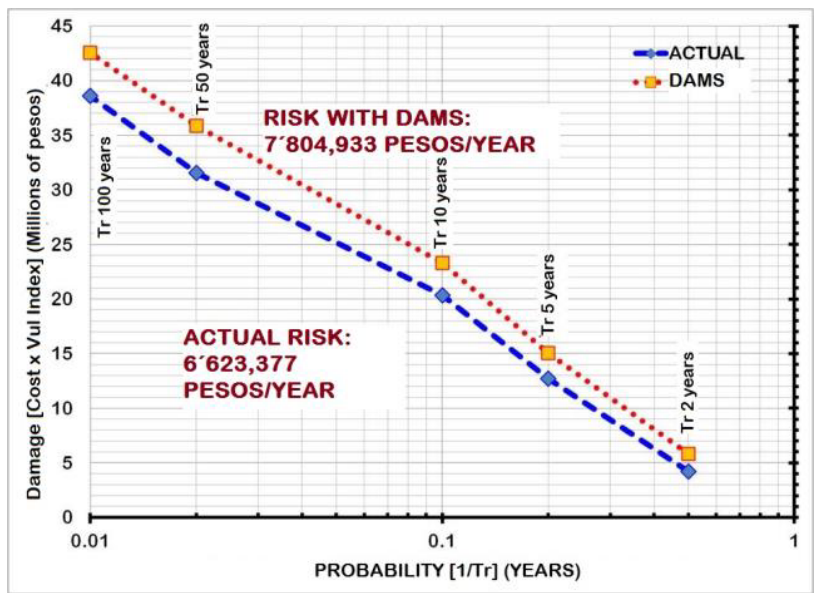

Figure 21 Comparison flood risk estimation in housing

\section{Conclusions}

With the growing concern over the increase in the frequency and severity of disasters and natural hazards, and the substantial reduction of losses in environmental, economic and social assets the risk analysis become very important.

The analysis presented in this paper is: in the range of 0 to $\$ 600$ / year, affecting about $92 \%$ of households, corresponding to 5,763 of them. It is the largest percentage falls on the poorest households.
However, the higher cost range belongs to the range between 36.000 to $\$ 58.000$ / year where only 44 homes are affected with a rate of $0.7 \%$. This means that the most expensive houses where the depth and / or speed are considerably large not represent even $1 \%$ of total damages.

Not necessarily the works proposed reduce flood damages. Sometimes the water that temporarily occupied an area of land can be moved to other regions where it could cause further injury, therefore, it is convenient to carry out comprehensive studies of a whole watershed to evaluate the goodness of the proposed works, usually with simulation surface flow models covering the basin where flood areas are located.

An important point of analysis leads us to consider that a large number of houses affected with a small economic value results in a large economic damage, affecting the most vulnerable population; the resilience of this segment of the population in the town need more recovery time.

Therefor a fundamental tool for decision making after a flood is risk analysis.

\section{References}

1. Baeza, R. C. (2007). "Estimación regional de factores de convectividad para el cálculo de las relaciones intensidad-duración-frecuencia”. Tesis de Maestría. Universidad Nacional Autónoma de México.

2. Baró, Suarez José Emilio. "Costo más probable de daños por inundación en zonas habitacionales de México", septiembre 2011.

3. Chen, C. L. (1983). Rainfall Intensity-DurationFrequency Formulas. Journal of Hydraulic Engineering, ASCE, Vol. 109, No. 12, December 1983, pp. 1603-1621.

4. Chow, V. T. (1994). "Hidrología Aplicada". McGraw-Hill Interamericana, S.A., Colombia.

5. CENAPRED, (2004).”Guía Básica para la elaboración de Atlas Estatales y Municipales de Peligros y Riesgos", 1ª Edición Diciembre 2004.

6. Fuentes, M. O. A. (2012). "Obtención de hietogramas correspondientes a diferentes periodos de retorno", XXV Congreso Latinoamericano de Hidráulica, San José, Costa Rica.

7. Maidment, D. R. (1993). Handbook of Hydrology. McGraw-Hill Inc., USA.

8. Metodología para la Elaboración de Mapas de Riesgo por Inundaciones en Zonas Urbanas. Centro Nacional de Prevención de Desastres. Serie: Atlas Nacional de Riesgos. Fenómenos Hidrometeorológicos. Marco Antonio Salas, Julio 2011.

9. OMM, Gestión Integrada de Crecidas: Documento Comceptual. Organización Meteoorológica Mundial. OMM-No.1047. Ginebra, Suiza 2009.

10. OMM, Tercera Conferencia Mundial sobre el clima, Ginebra, Suiza, 31 de agosto-4 de septiembre de 2009. 
11. Paoli, Carlos U. Curso Gestión Integrada de Crecidas, Facultad de Ingeniería y Ciencias HídricasUniversidad Nacional del Litoral. Centro Regional Litoral-Instituto Nacional del Agua.-Prof. Ing. Carlos U. Paoli, Santa Fe Argentina, 26 al 30 de abril de 2010 . 